Personally, I strongly disapprove of the action of the March 11th, 1899, concerning my late father's paper entitled

General Medical Council in instituting this prosecution and I think Mrs. Hunter is deserving of much sympathy.

I am, Sirs, yours faithfully,

Robert A. Fryer, M.B. Edin.

New North-road, N., March 22nd, 1899.

\section{"SALIPYRIN IN INFLUENZA."}

To the Eatitors of THE LANCET.

SiRs,-In THe LANCET of March 18th appears a letter from Dr. Butler Harris drawing attention to the excellent results obtained by the use of salipyrin in influenza. As I have been using a similar compound for two or three years with most rapid relief of the headache, backache, fever, and malaise of influenza, and without any untoward symptoms following its use, I beg to submit it to the readers of THE LANCET. The formula I generally use is as follows: acetanilide, 30 grains; spirit of chloroform, two drachms; spirit of camphor, one drachm; salicylate of soda, one and a half drachms ; water to six ounces; one ounce to be taken every four hours until relieved. In dispensing this, owing to the slight solubility of acetanilide, the spirit should be added first and the water added by degrees. The mixture contains always light focculent crystalline masses floating near the surface and directions have to be given that the mixture must be well shaken each time of taking. Even in cases where the pulse is most feeble I have seen rapid improvement without the slightest bad symptom, evidently owing in some measure to the stimulating effect of the camphor and alcohol. In most cases the sense of relief is attended by copious perspiration. The cost of the above combination is so much less than salipyrin that I recommend it especially to those practitioners who like myself have a great number of poorer-class patients who cannot afford to pay for very expensive prescriptions. I have three times had occasion to use it myself when attacked by influenza and each time with rapid convalescence, and in over 100 cases among my patients the compound has been invariably successful.

I am, Sirs, yours faithfully,

H. LyoN SMITH, M.R.C.S. Tng., L.R.C.P. Edin.

Narch 12th, 1899

\section{SURGERY OF PANCREATIC TUMOURS.}

To the Editors of THE LANCET.

SrRS,-In the discussion on Mr. Barker's paper at the Clinical Society of London ${ }^{1}$ I said that Krönlein had removed a tumour, not a "cyst," as reported. It was an angio-sarcoma "as big as a fist." His original communication, with a fine coloured drawing of the post-mortem appearances, will be found in the Beiträge zur Klinischen Chirurgie, vol. xiv., 1895, p. 663. A solid tumour of the pancreas, if not left alone altogether, must be taken away, as there can be no question of drainage.

I am, Sirs, yours faithfully, ALiBAN DORAN.

Granville-place, Portman-square, W., March 21st, 1899.

\section{"THE INFECTIOUSNESS OF PHTHISIS."}

To the Editors of THE LANCET.

SIRS,-I see that in an annotation in THE LANCET of March 18th dealing with the action brought by the Leas Hotel Company against the executors of the late Radclyffe Hall it is stated that a witness for the defence said that my father, the late Dr. C. E. Fitz-Gerald, had certified the cause of death wrongly. I think it is a thousand pities that I was not called as a witness in the case, as I also saw the deceased once during life, my father having seen him twice, and having ample opportunity to ascertain the nature of the disease I could have positively asserted that in $\mathrm{my}$ opinion my father's certificate was right and that acute pulmonary phthisis was the cause of death. I have already certified the same for an insurance company and have also carried on a correspondence concerning the disinfection necessary with both the manager of the hotel and also the solicitor to the deceased. It is extremely unpleasant to us to have my late father's certificate impugned.

With regard to a matter appearing in THE LANCET of
" The Just Position of Bacteriology," may I be allowed to state that $I$ have no acquaintance whatever with Mr. Maurice L. Johnson and that his letter quoting my father's late paper was entirely outside my knowledge? The paper was my father's last and the view taken was a favourite one with him and I published it out of respect for his memory.

I am, Sirs, yours faithfully,

E. D. Fitz-Gerald, M.R.C.S. Eng., L.R.C.P. Lond. Folkestone, Marnh 20th, 1899

\section{MONOPOLIES IN THERAPEUTICAL MEASURES.}

To the Editors of THE LANCET.

SIRs,-The letter of Mr. Tallerman which appeared in THE LANCET of March 18th supports only too strongly the grave objection which I have long felt in common with many balneologists in this country to the altogether unnecessary interference on the part of lay inventors in the domain of therapeutics. No department of medical practice is perhaps more open to exploitation of this objectionable character than that presented by balneological therapeutics, but it is only within the past four or five years that we have been confronted by a new and more grave aspect of this evil. Hitherto we have been accustomed to the competition of that large army of unqualified practitioners (male and female) which derives such wide support at the hands of a credulous public, but now we are met by claims on the part of outsiders the character of which will be better realised when the profession has had time to grasp their full significance.

The medical profession, in this country at least, is made up very largely of men who devote a great part of their lives and much money to investigating disease and devising methods for the alleviation and cure of human suffering, and " cursed" in the eyes of his professional brethren would be the medical man who refused to make known any useful discovery or who by patent law or otherwise should limit to his own selfish ends the therapeutic value of any method of treatment whatsoever. Is it tolerable, then, that we should be asked not only to sanction but to support outside the profession practices which we justly condemn within our own ranks? In expressing these views I hold no brief for any particular hot-air apparatus. In truth, although I recognise certain advantages pertaining to each $I$ consider them all to be more or less mere adaptations of principles and methods long known in balneological practice.

In conclusion, and briefly, I would put the case thus. If the medical profession does not possess men sufficiently scientific and inventive to devise suitable and efficient apparatus to carry out its own methods of treatment let us at least demand from the outside inventor, as a condition precedent to our recommending or using his apparatus, that he shall apply to it the same principle of free and unrestricted use which we are ourselves in the habit of applying under similar circumstances.

Buxton, March 18th, 1899.

I am, Sirs, yours faithfully,

\section{"THE TALLERMAN TREATMENT AND ITS COUNTERFEITS."}

\section{To the Editors of THE LANCET.}

SIRS,--I have read with surprise Mr. Tallerman's letter in your issue of the 18 th inst. ...... In reply to the letter I may safely leave the press and the profession to take care of themselves. With regard to myself I totally deny the suggestion that I was aware of any apparatus at $\mathrm{Mr}$. Tallerman's or elsewhere of a similar character to my own being in existence at the time my patent was granted and in this opinion I am supported by a leading firm of patent agents, who, at my request, made a most exhaustive search at the Patent Office.

I am, Sirs, yours faithfully, ARTHUR E. GREVILLI.

Upper Berkeley-street, Portman-square, W.

** This controversy must now cease in our columns. We omit certain personalities from Mr. Greville's letter.-ED. L. 